\title{
Density and Sowing Season of Two Brachiaria Species on the SOYBEAN CULTURE ${ }^{1}$
}

\author{
Densidade e Época de Semeadura de Duas Espécies de Brachiaria sobre a Cultura da Soja
}

\author{
SARAIVA, A.S. ${ }^{2}$, ERASMO, E.A.L. ${ }^{3}$, MATA, J.F. ${ }^{4}$, DORNELAS, B.F. ${ }^{5}$, DORNELAS, D.F. ${ }^{5}$, and \\ SILVA, J.I.C. ${ }^{6}$
}

\begin{abstract}
The aim of this study was to evaluate the growth and yield of soybean cultivar M-8766 in consortium with Brachiaria brizantha. BRS Piata and Brachiaria ruziziensis at different densities and sowing dates. The experimental design was randomized blocks with treatments arranged in a factorial $2 \times 2 \times 3$ with four replications. Used as factors grass species (Brachiaria brizantha Piata and Brachiaria ruziziensis BRS) intercropped with soybean M-8766, sowing dates (12 and 24 days after soybean emergence) and three seeding rates $\left(0,5,10 \mathrm{~kg} \mathrm{ha}^{-1}\right.$ of seed). At 71 days after soybean emergence were evaluated plant height, stem diameter, dry mass of leaves, stems and shoots, and 4 months after sowing determined the weight of 100 grains and soybean yield. The results showed that when seeded at a density of $10 \mathrm{~kg} \mathrm{ha}^{-1}$ at 12 and 24 DAE soy, Brachiaria brizantha. BRS Piata caused reduction in yield in the order of $6.71 \%$ and $3.03 \%$ respectively, while the Brachiaria ruziziensis was one that caused a greater reduction in productivity in the order of 13.42 and $16.23 \%$, respectively, of these values expression when considering the price of soybean sack. B. ruziziensis expressed less competitive with soybean. However, the large biomass production of this grass provides deployment system till the next harvest.
\end{abstract}

Keywords: competition, Glycine max, Brachiaria brizantha, Brachiaria ruziziensis, crop-livestock integration, system holy faith.

\begin{abstract}
RESUMO - O objetivo deste trabalho foi avaliar o crescimento e a produtividade do cultivar de soja $M$ 8766 em consórcio com Brachiaria brizantha cv. BRS Piatã e Brachiaria ruziziensis, em diferentes densidades e épocas de semeadura. O delineamento experimental utilizado foi em blocos casualizados, com os tratamentos distribuidos em esquema fatorial $2 \times 2 \times 3$, com quatro repetições. Utilizaram-se como fatores espécies de capim-braquiária (Brachiaria brizantha cv. BRS Piatã e Brachiaria ruziziensis) consorciada com a cultura da soja $M-8766$, épocas de semeadura (12 e 24 dias após a emergência da soja) e três densidades de semeadura (0, 5 e $10 \mathrm{~kg}$ de semente ha $\left.{ }^{-1}\right)$. Aos 71 dias após a emergência da soja, foram avaliados a altura das plantas, o diâmetro do caule e a massa seca de folhas, caule e parte aérea; quatro meses após a semeadura, determinou-se o peso de 100 grãos e a produtividade da soja. Os resultados evidenciaram que, quando semeada na densidade de $10 \mathrm{~kg} \mathrm{ha-1}$ aos 12 e 24 DAE da soja, Brachiaria brizantha $c v$. BRS Piatã ocasionou redução na produtividade na ordem de 6,71 e 3,03\% respectivamente, enquanto Brachiaria ruziziensis foi a que mais reduziu a produtividade: na ordem de 13,42 e 16,23\%, respectivamente - valores estes de expressão quando se considera o preço da saca de soja. B. ruziziensis expressou menor competitividade com a cultura da soja; contudo, a grande produção de biomassa dessa graminea propiciou a implantação do sistema de plantio direto na safra seguinte.
\end{abstract}

Palavras-chave: competição, Glycine max, Brachiaria brizantha, Brachiaria ruziziensis, integração lavoura-pecuária, sistema Santa Fé.

Recebido para publicação em 10.5.2012 e aprovado em 26.11.2012.

2 Mestrando em produção vegetal, Universidade Federal do Tocantins - UFT, Gurupi-TO; <althierissaraiva@yahoo.com>; ${ }^{3}$ Professor, Dr., Adjunto, UFT, Gurupi-TO; ${ }^{4}$ Doutorando em Agronomia - Produção Vegetal, Unesp, Jaboticabal-SP; ${ }^{5}$ Graduado em Agronomia, UFT, Gurupi-TO; ${ }^{6}$ Pós-Doutorando em Agronomia, UFT, Gurupi-TO.

Planta Daninha, Viçosa-MG, v. 31, n. 3, p. 569-576, 2013 


\section{INTRODUCTION}

Soybean is of great importance for humanity, because of the abundant applicability of its products, ease of cultivation and international appreciation, and that is why it has been expanding in our country (Sediyama et al., 1993).

Due to a well developed production technology, this culture has expanded its cultivation in areas previously regarded as unsuitable and it has been used as a tool for the improvement of degraded pasture areas, mainly in the Cerrado (Mata et al., 2011). However, management before the planting of soybeans in no-till system is critical to the development of this culture. The removal of weeds before sowing allows initial development free from interference, while providing greater operational efficiency and uniformity of sowing (Jaremtchuk et al., 2008).

One of the alternatives for the expansion of soybean sowing, without having to open new areas, has been the intercropping of legume with forages, thus resulting in crop-livestock integration. According to Macedo (2009), such integration meets the complex needs of both livestock and agriculture, and it is an alternative for the recovery of degraded pastures, employment of no-tillage, breaking of pest and disease cycles, improvement of soil properties, full use of equipment, increasing of jobs and income in rural areas.

Among the options for crop-livestock integration, there is the Santa Fe system. In this system, forage is sown together or after crop sowing (Mata et al., 2011). According to Gorgen et al. (2010), besides promoting the production of fodder for offseason, the Santa Fe system enables the acquisition of high quality mulch, suitable for conducting notillage in tropical conditions.

Some of the most commonly used tropical forage species in this kind of intercropped system has been the Brachiaria species (Pariz et al., 2009). According to Portes et al. (2000), Brachiaria brizantha has excelled in intercropping of tropical forage species. However, Silva et al. (2005) emphasize that the feasibility of intercropping soybean and $B$. brizantha depends on the proper management of forage, minimizing competition and allowing good soybean and $B$. brizantha biomass yield. Another species recommended for this type of cultivation, according to Pariz et al. (2010), is Brachiaria ruziziensis, because it provides rapid ground cover, good chemical composition, excellent nutrient recycling, ease in its drying, and uniform seed production.

Within this context, for the establishment of the intercropping system, it is crucial to assess the factors that can alter the competitive balance of the system, such as the time and density of forage sowing in relation to culture, so that it does not cause economic losses in the production of the main crop. However, such coexistence forces the sharing of the same growth resources, and it can create a competitive relationship where one of the intercropped species may protrude over the other, depending on the type of cultivar used, on density and on the time of emergence of the species involved.

In view of the above, we may raise the hypothesis that forage in intercropping system can be considered similar to those weeds that arise spontaneously in the areas of soybean cultivation. Due to their low initial growth, soybean can be affected by the competition of Brachiaria, and one of the alternatives to reduce this competition is sowing of fodder in post-emergence of legume.

Thus, the aim of this study was to evaluate the growth and yield of soybean cultivar M 8766 intercropped with Brachiaria brizantha cv. BRS Piata and Brachiaria ruziziensis at different densities and sowing dates.

\section{MATERIALS AND METHODS}

The experiment was conducted from January to May 2010, at $280 \mathrm{~m}$ altitude and Aw climate, according to the climatic classification of Rubel \& Kottek (2010), defined as equatorial and dry winter. The average annual temperature is $29.5^{\circ} \mathrm{C}$, and average annual rainfall of $1804 \mathrm{~mm}$. The soil was classified as Red-yellow Oxisol Latosol and presented as chemical characteristics: $\mathrm{pH}$ $(\mathrm{CaCl})$ of $4.7, \mathrm{Ca}, \mathrm{Mg}, \mathrm{Al}$ and $\mathrm{Al}+\mathrm{H}$ of $2.1,0.4$, 0.2 and $2.7 \mathrm{cmol}_{\mathrm{c}} \mathrm{dm}^{-3}$, respectively, $\mathrm{P}$ (Melish) and $\mathrm{K}$ of 7.1 and $51.6 \mathrm{mg} \mathrm{dm}^{-3}$, respectively; 
CTC of $2.8 \mathrm{cmol}_{c} \mathrm{dm}^{-3} ; \mathrm{V}$ and $\mathrm{MO}$ of 49 and $1.9 \%$, respectively.

The experimental design was randomized blocks with treatments arranged in a factorial $2 \times 2 \times 3$ with four replications. Species factors were used of branchiaria grass (Brachiaria brizantha cv. BRS Piata and Brachiaria ruziziensis) intercropped with soybean M-8766, sowing dates (12 and 24 days after soybean emergence) and seeding rates $(0,5,10 \mathrm{~kg}$ seed ha-1).

Soil preparation was conducted in two stages: disc plow $(0.40 \mathrm{~m})$ and harrowing before planting. Liming was performed according to soil analysis and to the method of base saturation of CFSEMG (1999), to which was applied $1.485 \mathrm{t} \mathrm{ha}^{-1}$ of lime with $90 \%$ PRNT. Soybean seeds were inoculated with Bradyrhizobium japonicum. At the time of sowing, fertilization was carried out with $600 \mathrm{~kg} \mathrm{ha}^{-1}$ of 0-20-20, as recommended by soil test, and applied at plantation furrow.

Soybean sowing was conducted using the Semeato - SHM 11/13 drill on 01/07/2010, set to furrow openings spaced at $0.40 \mathrm{~m}$ and density of 12 seeds per linear meter, corresponding to 300,000 plants ha $^{-1}$, the emergence occurred on $01 / 12 / 2010$. Each plot consisted of $12 \mathrm{~m}^{2}$, with $2.0 \mathrm{~m}$ wide (five rows of $0.40 \mathrm{~m}$ ) by $6 \mathrm{~m}$ long.

At 12 and 24 days after seeding (DAS), the grass species were seeded with the same equipment, as proposed by the statistical design, in furrows spaced at $20 \mathrm{~cm}$ from the line of culture and in the depth of $3 \mathrm{~cm}$.

To determine soybean yield (5/9/2010), three central lines were harvested, and $2 \mathrm{~m}$ of each row was assessed. To assess height $(\mathrm{H})$, stem diameter (SD) and aerial part dry mass (APDM), stem dry mass (SDM) and leaves dry mass (LDM), six plants per portion were collected at 71 days after soybean emergence, to be the destructive sample. The assessment of plant height was performed using graduated scale, taking the measurement from the ground level to the apex of the leaves (with leaf blade distended) and stem diameter, using caliper from $5 \mathrm{~cm}$ of soil.

To determine the dry mass of the vegetative components, we separated the stem from the leaves from each plant; later, the plant material was packed in paper bags and placed in an oven with forced air circulation at $60{ }^{\circ} \mathrm{C}$ until constant weight.

Regarding production assessments, all plants from the useful area of the parcel were collected, and the following were determined: the weight of 100 grains for a fixed humidity of $13 \%$, and productivity, by calculating the weight of the grains collected in the area useful portion, expressed in $\mathrm{kg} \mathrm{ha}^{-1}$.

Data were subjected to analysis of variance and the means were compared by Tukey test $(\mathrm{p} \leq 0.05)$ using Sisvar.

\section{RESULTS AND DISCUSSION}

Data regarding rainfall and temperature are shown in Figure 1, emphasizing favorable conditions to the development of soybean plants.

Table 1 describes the average height and diameter of soybean stem grown alone and intercropped with Brachiaria brizantha cv. BRS Piata and Brachiaria ruziziensis at different densities and sowing dates.

The stem diameter of soybean plants was not significantly affected by any of the varieties of Brachiaria planted, nor by the density and sowing dates compared to soybean.

The height of soybean plants did not differ significantly in relation to the time of branchiaria sowing, yet in each sowing date there were differences among the seeding rates of forages.

In soybean sowing conducted both at 12 and $24 \mathrm{DAE}$, the largest reductions in plant height were observed in soybean seeding rate of $10 \mathrm{~kg} \mathrm{ha}^{-1}$ of Brachiaria brizantha and Brachiaria ruziziensis. At this density, B.brizantha caused a significant reduction in the height of soybeans: 7.08 and $6.55 \%$ compared to control (soybean growing up without the presence of grass) when sown at 12 and $24 \mathrm{DAE}$ of soybean, respectively. In the same situation, when soybean was intercropped with $B$. ruziziensis, these reductions corresponded to 7.08 and $5.48 \%$, respectively. 


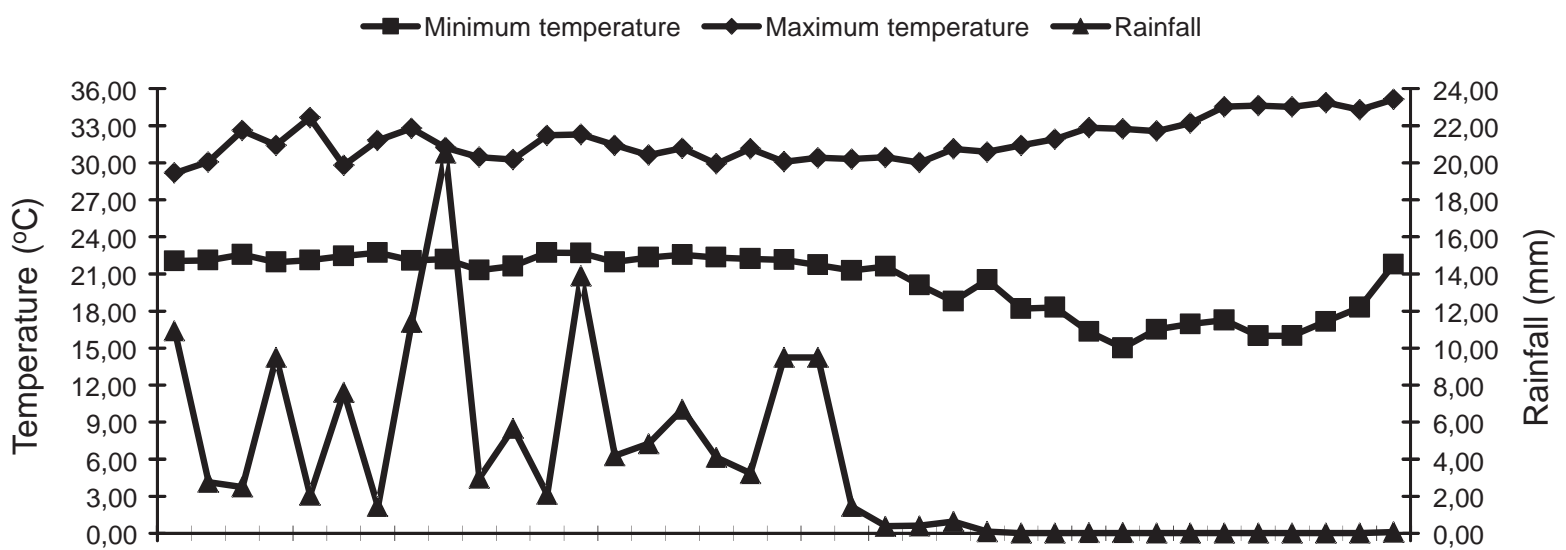

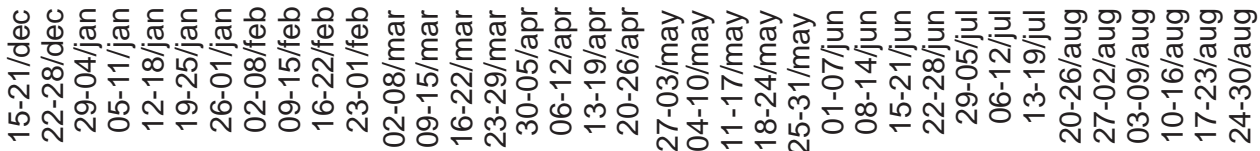

Week

Source: INMET/UFT.

Figure 1 - Minimum and maximum temperatures and rainfall during crop cycle in the 2009/2010 season. Gurupi-TO.

Table 1 - Stem height and diameter of soybean M-8766 RR grown alone and intercropped with Brachiaria brizantha cv. BRS Piata and Brachiaria ruziziensis at different densities (5 and $\left.10 \mathrm{~kg} \mathrm{ha}^{-1}\right)$ and sowing dates (12 and 24 DAE of soybean). Gurupi-TO 2009/2010 Crop

\begin{tabular}{|c|c|c|c|c|c|}
\hline \multirow{4}{*}{ Treatment } & \multirow{4}{*}{$\begin{array}{l}\text { Density } \\
\left(\mathrm{kg} \mathrm{ha}^{-1}\right)\end{array}$} & \multicolumn{4}{|c|}{ Soy } \\
\hline & & \multicolumn{2}{|c|}{ Stem diameter $(\mathrm{mm})$} & \multicolumn{2}{|c|}{ Height $(\mathrm{cm})$} \\
\hline & & \multicolumn{4}{|c|}{$\mathrm{DAE}^{1 /}$} \\
\hline & & 12 & 24 & 12 & 24 \\
\hline Witness & 0 & $7.37 \mathrm{aA}$ & $7.37 \mathrm{aA}$ & $85.63 \mathrm{aA}$ & $85.63 \mathrm{aA}$ \\
\hline \multirow{2}{*}{ B. brizantha } & 5 & $6.91 \mathrm{aA}$ & $7.08 \mathrm{aA}$ & $80.31 \mathrm{bcA}$ & $81.06 \mathrm{bcA}$ \\
\hline & 10 & $6.76 \mathrm{aA}$ & $6.91 \mathrm{aA}$ & $79.56 \mathrm{cA}$ & $80.02 \mathrm{cA}$ \\
\hline \multirow{2}{*}{ B. ruziziensis } & 5 & $7.09 \mathrm{aA}$ & $7.54 \mathrm{aA}$ & $83.19 \mathrm{abA}$ & $83.59 \mathrm{abA}$ \\
\hline & 10 & $6.84 \mathrm{aA}$ & $7.01 \mathrm{aA}$ & $79.56 \mathrm{cA}$ & $80.94 \mathrm{bcA}$ \\
\hline Cause of variation & & \multicolumn{4}{|c|}{ F calculated } \\
\hline Brachiaria & & \multicolumn{2}{|c|}{$0.647^{\mathrm{ns}}$} & \multicolumn{2}{|c|}{$0.136^{\mathrm{ns}}$} \\
\hline Density & & \multicolumn{2}{|c|}{$0.562^{\mathrm{ns}}$} & \multicolumn{2}{|c|}{$19.422 * *$} \\
\hline Period & & \multicolumn{2}{|c|}{$0.471^{\mathrm{ns}}$} & \multicolumn{2}{|c|}{$1.271^{\mathrm{ns}}$} \\
\hline Brachiaria $\mathrm{x}$ density & & \multicolumn{2}{|c|}{$1.487^{\mathrm{ns}}$} & \multicolumn{2}{|c|}{$3.403 *$} \\
\hline Brachiaria $\mathrm{x}$ period & & \multicolumn{2}{|c|}{$0.007^{\mathrm{ns}}$} & \multicolumn{2}{|c|}{$0.941^{\mathrm{ns}}$} \\
\hline Density $\mathrm{x}$ period & & \multicolumn{2}{|c|}{$1.990^{\mathrm{ns}}$} & \multicolumn{2}{|c|}{$0.651^{\mathrm{ns}}$} \\
\hline Brachiaria $\mathrm{x}$ density $\mathrm{x}$ period & & \multicolumn{2}{|c|}{$0.586^{\mathrm{ns}}$} & \multicolumn{2}{|c|}{$1.184^{\mathrm{ns}}$} \\
\hline \multicolumn{2}{|l|}{ CV $(\%)$} & \multicolumn{2}{|c|}{21.57} & \multicolumn{2}{|c|}{5.72} \\
\hline
\end{tabular}

$1 /$ Days after soybean emergence - DAE; * Means followed by the same letters, uppercase on rows and lowercase in columns, do not differ by Tukey test at $5 \%$ probability. ${ }^{*} \mathrm{e}^{* *}$ significant at 5 and $1 \%$ probability, respectively. ns: not significant.

A seeding rate of $5 \mathrm{~kg} \mathrm{ha}^{-1}$ of $B$. brizantha differed significantly from the control in both sowing dates, but no differences were found for B. ruziziensis. According to Zanine \& Santos (2004), a higher or lower density of plants, in a particular area, generates a distinctive 
productive behavior, because of competition for space, water, light and nutrients that is established in the plant community.

The increased competitive pressure from $B$. brizantha observed in the previous analysis confirms the results found by Santos et al. (2008) when assessing competition of soybean resistant to glyphosate and two weed species (Bidens pilosa and B. brizantha) in compacted soil. They found that the grass caused greater reduction in height, number of leaves and dry weight of soybean plants.

Silva et al. (2008), while studying weed densities and times of control over the components of soybean production, found that Brachiaria plantaginea, in areas of low infestation, was responsible for $80 \%$ of the total dry matter produced by plants. Its presence directly affects crop yields, and the damage varies according to the size of the crop, the duration of the competition and soil and weather conditions.

Considering the sowing date of brachiaria in relation to that of soybean, which was still in the vegetative stage, and taking into account the higher shading power of this culture, we believed that the depressive effect caused mainly by $B$. brizantha may be related to the difference in the speed and volume of root production in relation to the culture. It is crucial to consider the increased demand for nutrients caused by the forage.

$B$. brizantha has good shade tolerance, promoting elongation of stems and leaves as a form of light exposure, thus increasing the height of the grass, which may contribute for this species to present high competitive potential (Andrade et al., 2004; Soares et al ., 2009; Martuscello et al., 2009).

A hypothesis may be raised on the allelopathic effect of $B$. brizantha in relation to soybean crop, due to the production of allelochemicals by the forage, causing lower development of soybean plants.

Pacheco et al. (2008) state that cover crops, like $B$. ruziziensis and $B$. brizantha should be seeded when soybeans present R7 growth stage, which is characterized by early defoliation, so that they are still in suitable moist conditions for development; consequently they will have suitable plant height for the mechanical harvesting of soybean.

With regard to the dry matter of the soybean shoot (aerial part), the intercropping with Brachiaria brizantha sown at 24 DAE, at density of $10 \mathrm{~kg} \mathrm{ha}^{-1}$, caused an increase of $18.45 \%$ compared to the same density in sowing of soybean at 12 DAE (Table 2).

The sowing densities of $B$. brizantha significantly affected the dry mass accumulation of leaves, stems and shoots of soybeans, compared to control, in the sowing of soybeans at $12 \mathrm{DAE}$, but they did not differ between each other. In density of $10 \mathrm{~kg} \mathrm{ha}^{-1}$, reductions in these variables, compared to control, were $27.31,33.57$ and $27.76 \%$, respectively. When the roots of grass and soybeans compete for the same resources of soil, the one to stand out is that with greater root volume and increased nutritional requirements, resulting in greater potential for exploitation.

As for B. ruziziensis, these differences were only significant for density of $10 \mathrm{~kg} \mathrm{ha}^{-1}$ in the variables of leaves dry matter, stems dry matter and aerial part dry matter, in sowing of soybean at $12 \mathrm{DAE}$, with reduction of 19.75 , 29.81 and $24.19 \%$ respectively, in relation to control.

Silva et al. (2009), while studying sowing dates of $B$. brizantha intercropped with soybean in pots, found lower dry matter accumulation of soybean leaves (18 $\left.\mathrm{g} \mathrm{pot}^{-1}\right)$ when the forage emerged 21 days after soybean, which corresponded to $38 \%$ of the greater accumulation obtained by $B$. brizantha, which occurred when it emerged 21 days before soybean $\left(47 \mathrm{~g} \mathrm{pot}^{-1}\right)$.

B. ruziziensis expressed less competitiveness with soybean. However, the large biomass production of this grass encourages the employment of no-till system to the next crop. The lower competitive potential of $B$. ruziziensis may be related to seeding depth, which was $3 \mathrm{~cm}$. According to Pacheco et al. (2010), this grass provides satisfactory performance when sown on the surface $(0 \mathrm{~cm})$.

Both intraspecific and interspecific competition resulting from spatial competition 
Table 2 - Leaf dry matter (LDM), stem dry matter (SDM) and aerial part (shoots) dry mass (APDM) of soybean plant M-8766 RR grown alone and intercropped with Brachiaria brizantha cv. BRS Piata and Brachiaria ruziziensis at different densities (5 and $10 \mathrm{~kg} \mathrm{ha}^{-1}$ ) and sowing dates (12 and 24 DAE of soybean). Gurupi-TO. 2009/2010 Crop

\begin{tabular}{|c|c|c|c|c|c|c|c|}
\hline \multirow{3}{*}{ Treatment } & \multirow{3}{*}{$\begin{array}{l}\text { Density } \\
\left(\mathrm{kg} \mathrm{ha}^{-1}\right)\end{array}$} & \multicolumn{6}{|c|}{ Soy MSF $\left(\mathrm{kg} \mathrm{ha}^{-1}\right)$} \\
\hline & & \multicolumn{6}{|c|}{$\mathrm{DAE}^{1 /}$} \\
\hline & & 12 & 24 & 12 & 24 & 12 & 24 \\
\hline Witness & 0 & $798.14 \mathrm{aA}$ & $798.14 \mathrm{aA}$ & $1290.2 \mathrm{aA}$ & $1290.2 \mathrm{aA}$ & $2260.62 \mathrm{aA}$ & $2260.62 \mathrm{aA}$ \\
\hline \multirow{2}{*}{ B. brizantha } & 5 & $632.92 \mathrm{bcdB}$ & $762.34 \mathrm{aA}$ & $1031.48 \mathrm{bcA}$ & $1136.51 \mathrm{abA}$ & $1889.02 \mathrm{bcA}$ & $2162.34 \mathrm{aA}$ \\
\hline & 10 & $580.12 \mathrm{dA}$ & $660.9 \mathrm{aA}$ & $857.01 \mathrm{cB}$ & $1080.97 \mathrm{bA}$ & $1633.06 \mathrm{cB}$ & $2002.67 \mathrm{aA}$ \\
\hline \multirow{2}{*}{ B. ruziziensis } & 5 & $737.26 \mathrm{abcA}$ & $751.18 \mathrm{aA}$ & $1111.08 \mathrm{abA}$ & $1157.34 \mathrm{abA}$ & $2069.55 \mathrm{abA}$ & $2150.76 \mathrm{aA}$ \\
\hline & 10 & $640.46 \mathrm{bcdA}$ & $725.08 \mathrm{aA}$ & $905.56 \mathrm{bcA}$ & $1076.23 \mathrm{bA}$ & $1713.76 \mathrm{cA}$ & $2033.08 \mathrm{aA}$ \\
\hline Cause of variation & & \multicolumn{6}{|c|}{ F calculated } \\
\hline Brachiaria & & \multicolumn{2}{|c|}{$0.011^{\mathrm{ns}}$} & \multicolumn{2}{|c|}{$0.008^{\mathrm{ns}}$} & \multicolumn{2}{|c|}{$0.011^{\mathrm{ns}}$} \\
\hline Density & & \multicolumn{2}{|c|}{$2.078^{\mathrm{ns}}$} & \multicolumn{2}{|c|}{$2.977^{*}$} & \multicolumn{2}{|c|}{$2.905^{*}$} \\
\hline Period & & \multicolumn{2}{|c|}{$4.117^{*}$} & \multicolumn{2}{|c|}{$8.207 * *$} & \multicolumn{2}{|c|}{$7.430 * *$} \\
\hline Brachiaria $\mathrm{x}$ density & & \multicolumn{2}{|c|}{$0.028^{\mathrm{ns}}$} & \multicolumn{2}{|c|}{$0.226^{\mathrm{ns}}$} & \multicolumn{2}{|c|}{$0.103^{\mathrm{ns}}$} \\
\hline Brachiaria $\mathrm{x}$ period & & \multicolumn{2}{|c|}{$0.024^{\mathrm{ns}}$} & \multicolumn{2}{|c|}{$0.490^{\mathrm{ns}}$} & \multicolumn{2}{|c|}{$0.721^{\mathrm{ns}}$} \\
\hline Density x period & & \multicolumn{2}{|c|}{$8.425 * *$} & \multicolumn{2}{|c|}{$7.625 * *$} & \multicolumn{2}{|c|}{$10.457 * *$} \\
\hline Brachiaria $\mathrm{x}$ density $\mathrm{x}$ period & & \multicolumn{2}{|c|}{$5.720 * *$} & \multicolumn{2}{|c|}{$3.457 *$} & \multicolumn{2}{|c|}{$5.403 * *$} \\
\hline \multicolumn{2}{|l|}{ CV (\%) } & \multicolumn{2}{|c|}{27.84} & \multicolumn{2}{|l|}{27.72} & \multicolumn{2}{|c|}{3.86} \\
\hline
\end{tabular}

${ }^{1 /}$ Days after soybean emergence - DAE; * Means followed by the same letters, uppercase on rows and lowercase in columns, do not differ by Tukey test at $5 \%$ probability. ${ }^{*}$ e $* *$ significant at 5 and $1 \%$ probability, respectively. ns: not significant.

among groups of plants that occupy the same site within a given period of time, cause considerable reduction in the growth of species (Zanine \& Santos, 2004).

$B$. brizantha has greater capacity of nutrient uptake when soil $\mathrm{pH}$ is in an alkaline medium $(6,5)$, making it more competitive (Souza Filho et al. 2000). However, these present results show that even at acidic $\mathrm{pH}$ (4.7) plants of $B$. brizantha proved quite competitive when intercropped with soybean.

Table 3 shows data on the weight of 100 grains and yield of soybean grown alone and intercropped with Brachiaria brizantha $\mathrm{cv}$. BRS Piata and Brachiaria ruziziensis at different densities and sowing dates.

It was found that the densities and time of sowing of branchiaria did not significantly affect the weight of 100 grains of soybean and yield. Thus, it was found that when sown at a density of $10 \mathrm{~kg} \mathrm{ha}^{-1}$ at 12 and $24 \mathrm{DAE}$ of soybean, Brachiaria brizantha cv. BRS Piata has caused reduced productivity of 6.71 and $3.03 \%$ respectively, while Brachiaria ruziziensis has caused the greatest reduction in yield, of 13.42 and $16.23 \%$, respectively - values represented when considering the price of soybean sack.

Ferreira et al. (2009), in competition period effect studies for the morphological characteristics of soybean, found that both the coexistence period and the cultivation system may affect the size and weight of grains.

In an experiment conducted in pots, while assessing the influence of the sowing date of Brachiaria brizantha intercropped with soybean, Silva et al. (2005) found reductions in grain yield per plant of 80, 34, 27 and 15\%, corresponding, respectively, to $0,7,14$ and 21 days of emergency of $B$. brizantha in relation to soybean.

Silva et al. (2008), when studying weed densities and times of control over the production components of soybean, have found in areas of low, medium and high infestation, reductions of up to 58,71 and $78 \%$, respectively, in the number of pods per plant.

The seeding rate of $10 \mathrm{~kg} \mathrm{ha}^{-1}$ has caused the greatest reductions in the variables studied for soybean. The competitive effect of soybean M-8766 RR was higher when 
Table 3 - Weight of 100 grains and soybean M-8766 RR yield grown alone and intercropped with Brachiaria brizantha cv. BRS Piata and Brachiaria ruziziensis at different densities ( 5 and $10 \mathrm{~kg} \mathrm{ha}^{-1}$ ) and sowing dates (12 and 24 DAE of soybean). Gurupi-TO. 2009/2010 Crop

\begin{tabular}{|c|c|c|c|c|c|}
\hline \multirow{4}{*}{ Treatment } & \multirow{4}{*}{$\begin{array}{l}\text { Density } \\
\left(\mathrm{kg} \mathrm{ha}^{-1}\right)\end{array}$} & \multicolumn{4}{|c|}{ Soy } \\
\hline & & \multicolumn{2}{|c|}{ Weight 100 grãos (g) } & \multicolumn{2}{|c|}{ Yield $\left(\mathrm{kg} \mathrm{ha}^{-1}\right)$} \\
\hline & & \multicolumn{4}{|c|}{ DAES $^{1 /}$} \\
\hline & & 12 & 24 & 12 & 24 \\
\hline Witness & 0 & 12.17 & 12.17 & 3609.38 & 3609.38 \\
\hline \multirow{2}{*}{ B. brizantha } & 5 & 12.09 & 12.10 & 3500.00 & 3599.08 \\
\hline & 10 & 12.03 & 12.09 & 3367.19 & 3500.00 \\
\hline \multirow{2}{*}{ B. ruziziensis } & 5 & 11.71 & 11.99 & 3414.06 & 3507.81 \\
\hline & 10 & 11.40 & 11.90 & 3125.00 & 3023.44 \\
\hline Cause of variation & & \multicolumn{4}{|c|}{ F calculated } \\
\hline Brachiaria & & \multicolumn{2}{|c|}{$0.127^{\text {ns }}$} & \multicolumn{2}{|c|}{$0.221^{\mathrm{ns}}$} \\
\hline Density & & \multicolumn{2}{|c|}{$0.459^{\text {ns }}$} & \multicolumn{2}{|c|}{$1.999^{\mathrm{ns}}$} \\
\hline Period & & \multicolumn{2}{|c|}{$0.000^{\mathrm{ns}}$} & \multicolumn{2}{|c|}{$0.068^{\mathrm{ns}}$} \\
\hline Brachiaria $\mathrm{x}$ density & & \multicolumn{2}{|c|}{$0.265^{\mathrm{ns}}$} & \multicolumn{2}{|c|}{$0.057^{\mathrm{ns}}$} \\
\hline Brachiaria $\mathrm{x}$ period & & \multicolumn{2}{|c|}{$0.192^{\mathrm{ns}}$} & \multicolumn{2}{|c|}{$0.670^{\mathrm{ns}}$} \\
\hline Density $\mathrm{x}$ period & & \multicolumn{2}{|c|}{$0.452^{\mathrm{ns}}$} & \multicolumn{2}{|c|}{$0.045^{\mathrm{ns}}$} \\
\hline Brachiaria $\mathrm{x}$ density $\mathrm{x}$ period & & \multicolumn{2}{|c|}{$0.695^{\mathrm{ns}}$} & \multicolumn{2}{|c|}{$0.628^{\mathrm{ns}}$} \\
\hline \multicolumn{2}{|l|}{$\mathrm{CV}(\%)$} & \multicolumn{2}{|c|}{4.40} & \multicolumn{2}{|c|}{14.98} \\
\hline
\end{tabular}

1/ Days after soybean emergence - DAE; ns: not significant.

Brachiaria brizantha cv. BRS Piata and Brachiaria ruziziensis were sown 24 days after crop emergence. Brachiaria brizantha cv. BRS Piata expressed the most competitive behavior with soybean.

\section{ACKNOWLEDGEMENTS}

We would like to thank the Government of the State of Tocantins, the Department of Science and Technology-SECT, and the State Council of Science and Technology, CECT, for granting financial support; we would also like to thank the Federal University of Tocantins for supporting the development of our work."

\section{LITERATURE CITED}

ANDRADE, C. M. S. et al. Crescimento de gramíneas e leguminosas forrageiras tropicais sob sombreamento. Pesq. Agropec. Bras., v. 39, n. 3, p. 263-270, 2004.

\section{COMISSÃO DE FERTILIDADE DO SOLO DO ESTADO} DE MINAS GERAIS - CFSEMG. Recomendação para uso de corretivos e fertilizantes em Minas Gerais. 5a aproximação. Viçosa, MG, 1999. 359 p.

FERREIRA, D. F. Programa SISVAR. Sistema de Análise de Variância. Versão 4.6 (Build 6.0). Lavras. DEX/UFLA, 2003.
FERREIRA, E. A. et al. Estudos de efeitos de períodos de competição nas características morfológicas de grãos de soja R. Trópica - Ci. Agr. Biol., v. 3, n. 2, p. 59, 2009.

GORGEN, C. A. et al. Redução do inóculo inicial de Sclerotinia sclerotiorum em soja cultivada após uso do sistema Santa Fé. Pesq. Agropec. Bras., v. 45, n. 10, p. 1102-1108, out. 2010

JAREMTCHUK, C. C. et al. Efeito de sistemas de manejo sobre a velocidade de dessecação, infestação inicial de plantas daninhas e desenvolvimento e produtividade da soja. Acta Sci. Agron., v. 30, n. 4, p. 449-455, 2008.

MACEDO, M. C. M. Integração lavoura e pecuária: o estado da arte e inovações tecnológicas. R. Bras. Zootec., v. 38, p. 133-146, 2009 (Supl. Especial)

MARTUSCELLO, J. A. et al.Produção de gramíneas do gênero Brachiaria sob níveis de sombreamento. R. Bras. Zootec., v. 38, n. 7, p. 1183-1190, 2009.

MATA, J. F. et al. Análise de crescimento da Brachiária em diferentes densisdades e épocas de semeadura em consorcio com a cultura da soja. R. Bras. Tecnol. Aplicada Ci. Agr. v. 4, n. 3, p. 7-30, 2011

PACHECO, L. P. et al. Profundidade de semeadura e crescimento inicial de espécies forrageiras utilizadas para cobertura do solo. Ci. Agrotec., v. 34, n. 5, p. 1211-1218, 2010 .

Planta Daninha, Viçosa-MG, v. 31, n. 3, p. 569-576, 2013 
PACHECO, L. P. et al. Desempenho de plantas de cobertura em sobressemeadura na cultura da soja. Pesq. Agropec. Bras., v. 43, n. 7, p. $815-823,2008$

PARIZ, C. M. et al. Desempenhos técnicos e econômicos da consorciação de milho com forrageiras dos gêneros Panicum e Brachiaria em sistema de integração lavoura-pecuária. Pesq. Agropec. Trop., v. 39, n. 4, p. 360-370, 2009.

PARIZ, C. M. et al. Massa seca e composição bromatológica de quatro espécies de braquiárias semeadas na linha ou a lanço, em consórcio com milho no sistema plantio direto na palha. Acta Sci. An. Sci., v. 32, n. 2, p. 147-154, 2010

PORTES, T. A. et al. Análise do crescimento de uma cultivar de braquiária em cultivo solteiro e consorciado com cereais. Pesq. Agropec. Bras., v. 35, n. 7, p. 1349-1358, 2000 .

RUBEL, F.; KOTTEK, M. Observed and projected climate shifts 1901-2100 depicted by world maps of the KöppenGeiger climate classification. Meteorol. Z., v. 19, n. 2, p. 135-141, 2010.

SANTOS, J. B. et al. Competição entre soja resistente ao glyphosate e plantas daninhas em solo compactado. Planta Daninha, v. 26, n. 1, p. 123-130, 2008.
SEDIYAMA, T. et al. Cultura da soja. Viçosa, MG: Imprensa Universitária, 1993. v. 1.93 p.

SILVA, A. C. et al. Acúmulo de macro e micronutrientes por soja e Brachiaria brizantha emergida em diferentes épocas.

Planta Daninha, v. 27, n. 1, p. 49-56, 2009

SILVA, A. F. et al. Densidades de plantas daninhas e épocas de controle sobre os componentes de produção da soja. Planta Daninha, v. 26, n. 1, p. 65-71, 2008.

SILVA, C. A. et al. Caracteres morfológicos de soja e brachiaria consorciadas sob subdoses de fluazifop-p-butil. Ci. Rural, v. 35, n. 2, p. 277-283, 2005.

SOARES, A. B. et al. Influência da luminosidade no comportamento de onze espécies forrageiras perenes de verão. R. Bras. Zootec., v. 38, n. 3, p. 443-451, 2009.

SOUZA FILHO, A. P. S.; VELOSO, C. A. C.; GAMA, J. R $\mathrm{N}$. Capacidade de absorção de nutrientes do capim-marandu (Brachiaria brizantha) e da planta daninha malva (Urena lobata) em função do pH. Planta Daninha, v. 18, n. 3, p. 443-450, 2000.

ZANINE, A. M.; SANTOS, E. M. Competição entre espécies de plantas - uma revisão. R. FZVA, v. 11, n. 1, p. 10-30, 2004. 